\title{
Aplikasi Pengenalan Kebudayaan Provinsi Riau Berbasis Android
}

\author{
Yulisman $^{1}$, Serdiansah $^{2}$ \\ 1,2Program Studi Sistem Informasi, STMIK Hang Tuah Pekanbaru, \\ Jl. Mustafa Sari No. 5 Tangkerang Selatan, Pekanbaru, Riau, Indonesia \\ e-mail: yulismanaziera27@gmail.com
}

\begin{abstract}
Current technological developments have an impact on the application of technology in the field of education, especially in the learning process. SMA Negeri 1 Cirenti is a school located in Riau Province, Kuantan Singingi Regency. The learning process in SMA Negeri 1 Cirenti which has been done in a conventional way, namely the teacher explains the subject matter based on books and other supporting media such as material about the introduction of culture in Riau Province. The material is very important for students to preserve culture and customs in the future, and so that the material is more interesting, the use of technology as a learning media that can be accessed wherever students are. Smart phone technology can be utilized in the education sector by creating applications that are capable of supporting learning media. The purpose of this study is to design and create an Android-based mobile phone application as an application for learning introduction to culture in Riau Province. Making this application uses a prototype development method with eclipse software and java programming language, as well as for testing applications with the blackbox method. The results of this study are applications that introduce educative and interactive culture of Riau Province based on Android to students and teachers with applications that can be directly installed on a smart phone.
\end{abstract}

Keywords: Aplication, Cultural, Android, Eclipse, Java

\section{Pendahuluan}

Provinsi Riau merupakan salah satu Provinsi yang ada di Indonesia dan di pulau Sumatra. Provinsi Riau dikenal dengan Bumi Melayu yang mempunyai berbagai macam ragam kebudayaan, terutama di daerah Kabupatennya yang memiliki kebudayaan dan ciri khas masing-masing. Kebudayaan adalah gagasan yang digambarkan dalam model dan ciri khas pengetahuan daerah yang dijadikan dasar atau acuan oleh tingkah laku individu atau kelompok sebagai anggota masyarakat untuk melakukan aktivitas sosial, yang bisa menciptakan materi kebudayaan dalam unsur budaya secara umum di suatu daerah (Tumanggor, Kholis, \& Nurochim, 2017). Kebudayaan dan ciri khas dari setiap daerah meliputi tradisi, bahasa, lagu, tari, makanan, perangkat tradisional dan lainlain yang dimiliki setiap suatu tersebut. Pengenalan mengenai berbagai macam kebudayaan yang ada di suatu daerah terkhusus di Provinsi Riau yang dibahas pada penelitian ini sudah harus dimulai ketika masih anak-anak atau ketika masa pendidikan.

Pengenalan kebudayaan di masa pendidikan adalah cara terbaik untuk mengenalkan kebudayaan kepada siswa terutama tingkat pendidikan Sekolah Menengah Atas (SMA). Pendidikan merupakan suatu aktivitas yang terencana dan terstruktur untuk mewujudkan dan menciptakan sumber daya manusia yang unggul dan aktif dalam mengembangkan potensi dirinya yang didasarkan pada tekat untuk memperoleh kemampuan spritual keagamaan, pengedalian diri, kepribadian, kecerdasan, akhlak mulia, serta keterampilan yang diperlukan dirinya, masyarakat, bangsa dan Negara dengan melalui suatu proses pembelajaran diberbagai tingkatan (UU RI No. 20 Th. 2003, 2003). Melalui pendidikan pemerintah bisa memasukkan materi pembelajaran tentang kebudayaan yang ada di Indonesia, khususnya Provinsi Riau agar tetap dijaga dan dilestarikan oleh generasi selanjutnya.

SMA Negeri 1 Cerenti terletak di Jalan Ahmad Yani No 02, Desa Kompe Berangin Kecamatan Cerenti, Kabupaten Kuantan Singingi. SMA Negeri 1 Cerenti pada kelas X (Sepuluh) di mata pelajaran Ilmu Pengetahuan Sosial (IPS) membahas tentang pengenalan kebudayaan yang ada di Provinsi Riau. Metode pembelajaran yang digunakan oleh guru SMA Negeri 1 Cerenti selama ini dalam proses belajar dan mengajar berdasarkan buku dan gambar berkaitan dengan kebudayaan Provinsi Riau, karena proses pembelajaran yang dibatasi membuat guru tidak bisa menyampaikan materi tentang pengenalan kebudayaan yang ada di Provinsi Riau secara efektif dan efisien. 
Perkembangan teknologi dan infrastruktur penunjangnya tidak terbatas lagi dan telah hampir menyentuh seluruh aspek aktivitas manusia, salah satu aspek atau bidang pendidikan. Pemerintah berupaya untuk peningkatan mutu pendidikan melalui pemanfaatan teknologi dan infrastruktur, untuk dapat membantu proses kegiatan pembelajaran di Instansi pendidikan, yang disebut dengan teknologi pendidikan. Teknologi pendidikan merupakan sebuah sistem atau aplikasi yang dapat memfasilitasi tenaga pendidik dan peserta didik atau siswa/i untuk belajar lebih aktif, lebih luas, lebih banyak dan juga bervariasi dengan sumber referensi materi mata pelajaran yang terpercaya. Melalui infrastruktur/perangkat teknologi yang telah tersedia dari suatu sistem/aplikasi pembelajaran, peserta didik/siswa dapat belajar mandiri, dan juga proses pembelajaran dapat dilanjutkan atau dilakukan, kapan dan di mana saja tidak terbatas oleh ruang dan waktu. Bahan dan materi mata pelajaran yang mereka dapat dan pelajari juga bervariasi, tidak hanya dalam bentuk sajian teks dan paragraf, namun dapat lebih kaya dengan variasi kata yang menarik, visual, audio dan animasi. (Hasibuan, 2015)

Perkembangan tersebut teknologi juga tidak asing bagi peserta didik, seperti pemanfaatan teknologi internet sebagai media pendukung pembelajaran untuk memperoleh materi tambahan. Penggunaan internet oleh remaja atau peserta didik sangat tinggi, ini terbukti hasil penelitian yang dikutip kompas.com dengan judul penelitian "Keamanan pengguna media digital pada anak dan remaja Indonesia" yang dilakukan lembaga PBB untuk anak-anak, UNICEF, bersama dengan mitra, termasuk salah satunya kementrian komunikasi dan informatika dan Universitas Harvard (Amerika Serikat). Sebanyak 98\% anak remaja terutama dikalangan anak Sekolah Menengah Atas (SMA) sudah menggunakan smartphone dan mengetahui internet dan 79,5\% dianataranya adalah penggguna (Panji, 2014). Berdasarkan penelitian tersebut peserta didik/siswa menggunakan smartphone untuk hal-hal yang tidak berguna dan waktu mereka terbuang dengan sia-sia. Smartphone adalah telepon kecil yang bisa digenggam dan memiliki kemampuan dengan pengunaan, fungsi dan fasilitas komunikasi yang mirip dengan komputer dalam bentuk kecil (Daeng, Mewengkang, \& Kalesaran, 2017).

Smartphone bisa dimanfaatkan sebagai media pembelajaran untuk penerapan teknologi pendidikan, ini dikarenakan pada saat sekarang hampir seluruh peserta didik/siswa mempunyai smartphone terutama siswa Sekolah Menengah Atas (SMA), dan aplikasi smartphone berbasis android adalah solusi terbaik untuk memaksimal penerapan teknologi pendidikan tersebut yang selama ini digaungkan oleh pemerintah terkhusus di Provinsi Riau, di mana pada penelitian ini membahas tentang pembelajaran Kebudayaan Melayu Riau. Menurut Irawan Android merupakan perangkat lunak sistem operasi berbasis linux yang diimplementasikan untuk perangkat portable seperti telepon pintar (smartphone) dan komputer kecil atau tablet. Android menyediakan platform bebas (open source) dan bisa dirombak sesuai keinginan programmer untuk mengembangkan sistem/aplikasi hasil buatan sendiri yang bisa pada berbagai jenis perangkat dengan sistem android (Maisyaroh, Mulyani, \& Juanda, 2017). Aplikasi pembelajaran Kebudayaan Melayu Riau bisa dimanfaatkan guru dan peserta didik/siswa terutama SMA Negeri 1 Cerenti dalam proses pembelajaran baik di sekolah maupun di rumah. Aplikasi ini siswa dapat mengulangi pelajaran di rumah dengan metode yang lebih menarik karena sudah tidak lagi menggunakan buku tetapi sudah menggunakan android.

Peneliti sebelumnya juga pernah melakukan pengembangan dan pembuatan aplikasi smartphone berbasis android untuk media pembelajaran, dengan hasil bahwa aplikasi android bisa dikembangkan dan efektif dalam penyampaian informasi dan sumber informasi serta digunakan untuk media pembelajaran, setting ekosistem elearning (Zahid, 2018). Hasil penelitian yang lain tentang aplikasi pembelajaran berbasis android bahwa aplikasi layak dan menarik untuk kriteria atau dengan nilai baik, yang dapat dibuktikan dari hasil proses pengumpulan data menggunakan angket dan diperoleh hasil; dengan media pembelajaran berbasis android untuk mata pelajaran SOJ (Sistem Operasi Jaringan) untuk kelas sebelas layak untuk diimplementasikan di sekolah (Kuswanto \& Radiansah, 2018). Hasil uji pada penelitian berikut ini menyatakan efektivitas dari media/aplikasi pembelajaran berbasis Android yang diterapkan pada mata pelajaran Biologi dengan hasil, siswa secara aktif dan mandiri dalam pembelajaran materi biologi, karena sistem dirancang semenarik mungkin bagi peserta didik/siswa. (Muyaroah \& Fajartia, 2017). Hasil penelitian tentang aplikasi kebudayaan tradisional Indonesia berbasis android yang dapat dimanfaatkan sebagai media alternatif untuk mempermudah guru dan siswa/peserta didik dalam proses pembelajaran untuk mempelajari dan mengetahui sejauh mana pengetahuan siswa/peserta didik tentang kebudayaan tradisional Indonesia. (Nurfuadi, 2015) 


\section{Metode Penelitian}

Suatu akvitas penelitian harus menggunakan sebuah metode. Dengan disertai suatu metode, sebuah penelitian tidak akan menyipang jauh dari tema penelitian. Apa itu metode penelitian? Banyak pendapat dari ahli yang bisa diambil, dan peneliti menarik kesimpulan dari metode penelitian menurut Sugiyono intinya metode penelitian merupakan tahapan atau proses ilmiah dalam mengumpulkan data untuk memperoleh pengetahuan dengan teknik, maksud dan kegunaan tertentu (Widiyanto, 2018). Metode pembuatan dan pengembangan aplikasi pembelajaran pengenalan kebudayaan yang ada di Provinsi Riau berbasis android ini menggunakan metode model prototype. Metode model prototype cocok untuk aplikasi yang ingin terus di update atau dikembangkan kembali, dengan menyesuaikan perkembangan dunia pendidikan dan teknologi pembelajaran termasuk materi mata pelajaran, terkhusus materi pengenalan kebudayaan melayu di Provinsi Riau. Prototype merupakan metode yang menggunakan pendekatan pada objek penelitian secara langsung untuk membuat dan mengembangkan suatu sistem atau aplikasi dengan cepat dan berdasarkan tahapan yang ditentukan sehingga proses dievaluasi dapat segera dilakukan dan uji oleh pengguna sesuai dengan cakupan sistem/aplikasi yang dikembangkan (Rifa'atunnisa, Satria, \& Cahyana, 2014). Berikut gambaran metode prototype menurut Pressman:

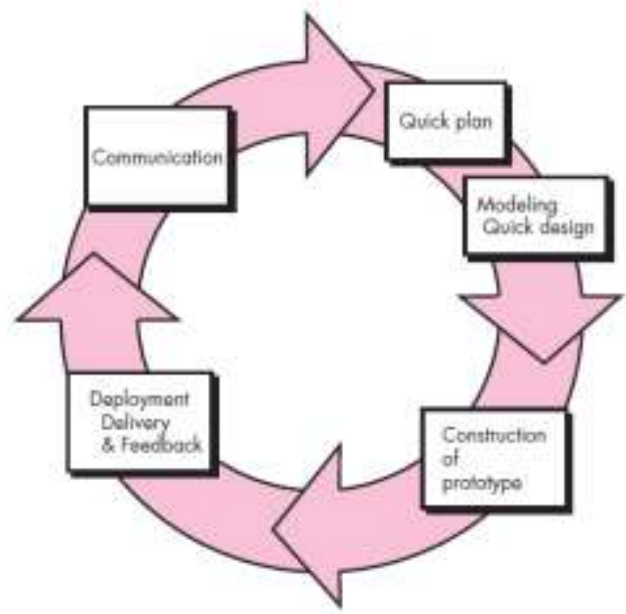

Gambar 1. Model Proses Prototype (Pressman, 2012)

Dari gambar $1 \mathrm{di}$ atas terdapat ada proses yang harus diikuti oleh pengembang aplikasi dalam membuat perangkat lunak, Proses-proses dalam model prototyping yaitu: a. Komunikasi (Communication), proses komunikasi pertama dilakukan secara langsung antara pengguna (guru dan peserta didik/siswa) dengan peneliti mengenai spesifikasi kebutuhan aplikasi yang diinginkan. Komunikasi yang dilakukan peneliti terdiri dari:

1. Pengamatan langsung (Observasi)

Proses pengamatan ini dilakukan langsung oleh peneliti dengan datang ke SMA Negeri 1 Cirenti. Peneliti mengamati langsung proses pembelajaran di kelas, terutama materi tentang pengenalan kebudayaan Melayu Riau dengan membaca buku yang terkait. Pengamatan ke rumah siswa juga dilakukan peneliti untuk mengetahui proses pengulangan materi tentang pengenalan kebudayaan Melayu Riau oleh siswa di rumah.

2. Wawancara (interview)

Wawancara merupkan salah satu proses komunikasi yang dilakukan peneliti dalam memperoleh informasi lebih untuk mendukung pembuatan/pengembangan aplikasi pembelajaran tentang pengenalan kebudayaan Melayu Riau berbasis android. Peneliti melakukan wawancara dengan staff guru dan juga siswa

3. Studi pustaka

Proses komunikasi berikutnya melakukan studi studi pustaka untuk memperoleh sumber utama yang dapat dijadikan sebagai rujukan dan informasi pendukung dalam pembuatan/pengembangan aplikasi pembelajaran tentang pengenalan kebudayaan Melayu di Provinsi Riau berbasis android. Sumber-sumber yang digunakan peneliti, seperti buku, artikel dan juga browsing di internet untuk melengkapi sumber rujukan.

b. Perencanaan dan pemodelan secara cepat (Quick and Modeling Quick Design), Pada proses ini peneliti melakukan rancangan cepat untuk menggambarkan kebutuhan pengguna (guru dan peserta didik/siswa) dan mewakili semua aspek aplikasi smartphone sebagai media pembelajaran tentang pengenalan kebudayaan Melayu di Provinsi Riau berbasis android yang diketahui dan kemudian akan menjadi dasar pembuatan prototype. Perancangan pemodelan aplikasi smartphone pengenalan kebudayaan Melayu di Provinsi Riau berbasis android ini menggunakan UML (Unified Modeling Language). UML (Unified Modeling Language) adalah seperangkat konvensi atau bahasa yang dinotasikan ke dalam sebuah simbol yang 
digunakan untuk mendokumentasikan, menspesifikasikan, menggambarkan atau menganalisis kebutuhan sebuah sistem/apliklasi dalam objek tertentu (Yusuf \& Kaniawulan, 2015). Berikut perancangan pemodelan untuk membuat aplikasi pengenalan kebudayaan Melayu di Provinsi Riau berbasis android:

1. Use Case Diagram

Use case diagram menggambarkan alur kebutuhan dan aktivitas sistem atau aplikasi dengan pengguna yang berdasarkan pada proses komputerisasi. Sebuah model use case dapat menggambarkan konektivitas dan alur komunikasi antara use case dengan actor. Secara umum use case adalah pola tingkah laku sistem atau aplikasi dengan urutan koneksi yang saling berhubungan dan dilakukan oleh satu actor (Sujono, Mayasari, $\&$ Koloniawan, 2019). Berikut gambaran Use case aplikasi pengenalan kebudayaan Melayu di Provinsi Riau berbasis android:

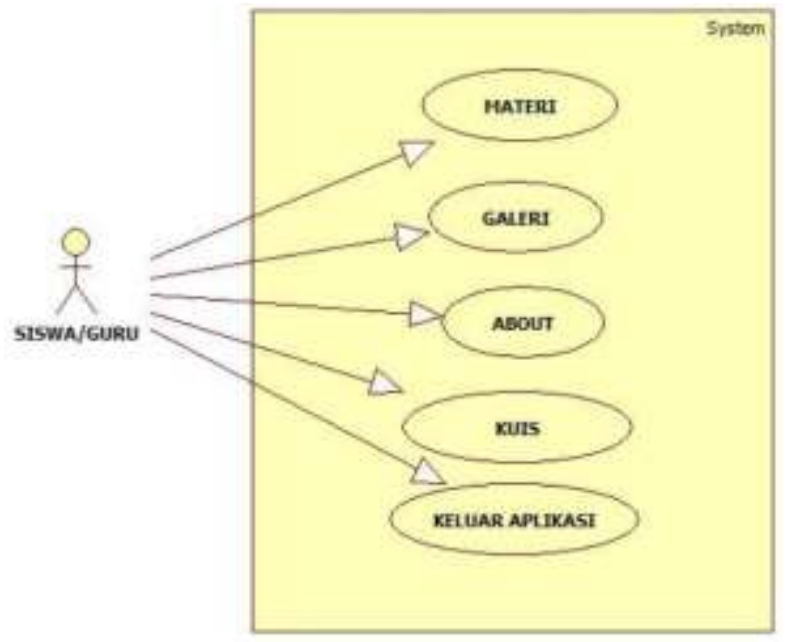

Gambar 2. Use Case Diagram

Berdasarkan gambar use case diagram di atas dapat dijelaskan sebagai berikut: 1 . Materi yaitu menampilkan pembelajaran tentang pengenalan kebudayaan Provinsi Riau yang bisa di akses oleh guru dan siswa; 2. Galeri yaitu menampilkan foto sekolahan SMA Negeri 1 Cerenti dan Kampus STMIK Hang Tuah Pekanbaru; 3. About yaitu menampilkan Tentang aplikasi; dan 4. Keluar Aplikasi yaitu keluar dari halaman aplikasi.

\section{Activity Diagram}

Activity Diagram merupakan representasi gambaran urutan kerja suatu proses bisnis sebuah aplikasi, sangat mirip dengan flowchart karena memodelkan dan menjelaskan bisnis dan operasional secara tahap per tahap dengan aktivitas ke status (Kosidin \& Farizah, 2016). Activity Diagram juga menggambarkan alur kontrol terhadap aktivitas pengguna aplikasi. Berikut gambaran Use case aplikasi pengenalan kebudayaan Melayu di Provinsi Riau berbasis android:

a) Activity Diagram Guru

Menggambarkan alur aktivitas guru pada aplikasi pengenalan kebudayaan Melayu di Provinsi Riau berbasis android, dapat dilihat pada gambar berikut:

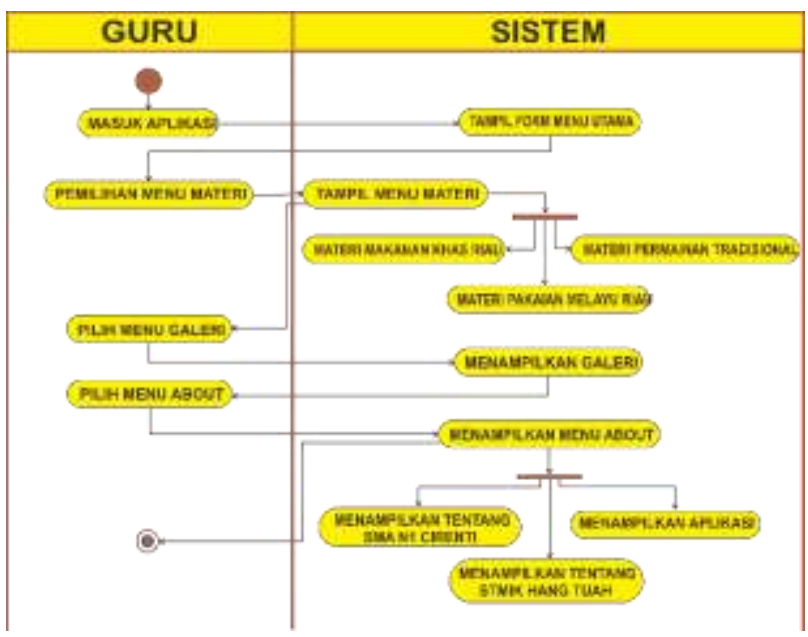

Gambar 3. Activity Diagram Guru

b) Activity Diagram Peserta Didik/Siswa Menggambarkan alur aktivitas peserta didik/siswa pada aplikasi pengenalan kebudayaan Melayu di Provinsi Riau berbasis android, dapat dilihat pada gambar berikut:

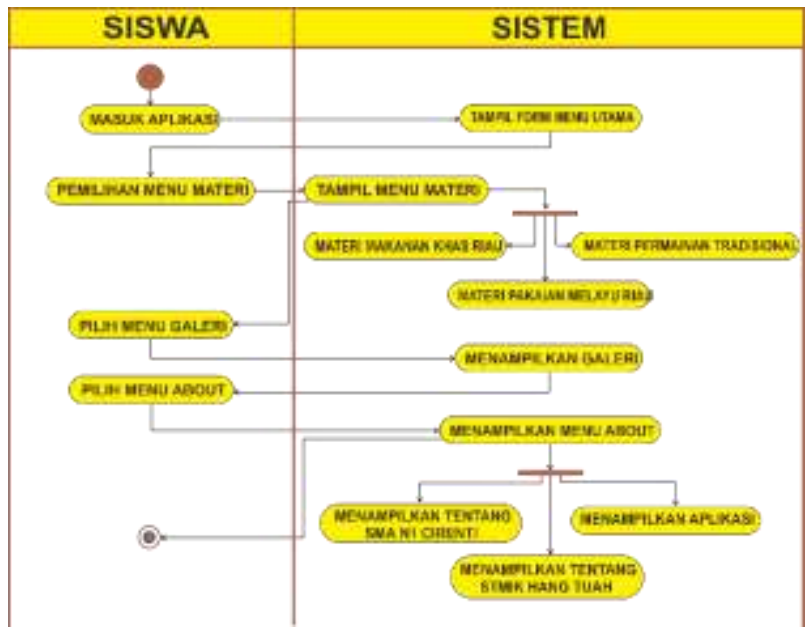

Gambar 3. Activity Diagram Peserta Didik/Siswa 
Berdasarkan gambar Activity Diagram di atas dapat dijelaskan kondisi saat pertama kali dijalankan oleh siswa dan guru. Halaman awal merupakan langkah pertama yang akan dijumpai oleh siswa, apabila siswa memilih menu materi maka akan muncul beberepa materi yang tersedia.

c. Membuat prototipe (Construction of Prototype), Pada tahap ini, peneliti melakukan perancangan dan pembuatan prototype aplikasi smartphone sebagai media pembelajaran tentang pengenalan kebudayaan Melayu di Provinsi Riau yang berbasis android. Prototype yang dibuat akan disesuaikan dengan kebutuhan aplikasi yang telah dianalisis dan didefinisikan sebelumnya berdasarkan kebutuhan pengguna (guru dan peserta didik/siswa). Prototype yang telah dibuat, kemudian akan dilakukan peninjauan ulang untuk dievaluasi apakah prototype aplikasi telah memenuhi spesifikasi kebutuhan pengguna, jika masih ada kekurangan, peneliti kembali mendengarkan dan mencatat saran dan kritik dari pengguna untuk memperbaiki prototype yang ada, sebelum dilakukan pengkodingan atau membuat aplikasi berdasarkan prototype yang telah jadi.

d. Penyerahan perangka lunak dan umpan balik (Deployment Delivery and Feedback), tahap berikutnya peneliti melakukan pembuatan aplikasi smartphone sebagai media pembelajaran tentang pengenalan kebudayaan Melayu di Provinsi Riau yang berbasis android sampai aplikasi selesai dikerjakan. Aplikasi dibangun berdasarkan dengan model prototype telah disetujui dan sebelumnya juga telah dievaluasi dan direvisi oleh pengguna, kemudian aplikasi yang sudah selesai akan diserahkan kepada pegguna (pihak sekolah dan stakeholdernya). Aplikasi akan diuji dan dievaluasi oleh pengguna untuk mengetahui apakah kebutuhan dari pengguna sudah terpenuhi, dan jika masih ada kebutuhan pengguna yang belum terpenuhi, maka aplikasi akan revisi dan kembali proses awal dan sampai kebutuhan pengguna terpenuhi, kemudian diserahkan kepada pengguna.

\section{Hasil dan Pembahasan}

Hasil dari penelitian sangat bergantung metode penelitian dan model pengembangan perangkat lunak/aplikasi. Model metode penelitian yang sudah ditentukan di atas yaitu model prototype, dan untuk memodelkan sebuah sistem/aplikasi (perangkat lunak), metode model prototyping memiliki tahapan-tahapan di dalam proses pembuatan dan pengembangannya. Tahapan inilah yang nantinya akan menentukan kesuksesan pengembangan dari sebuah sistem/aplikasi (perangkat lunak). Pengembang sistem/aplikasi (perangkat lunak) harus teliti dan memperhatikan tahapan dalam metode model prototyping agar hasil sistem/aplikasi (perangkat lunak) dapat diterima dan digunakan oleh pengguna dengan mudah, berikut tahapan-tahapan dalam metode model prototyping tersebut:

a. Pengumpulan kebutuhan

Pengumpulan kebutuhan ini adalah kebutuhan aplikasi yang dilakukan oleh pengguna dan peneliti bersama-sama menganalisis dan mendefinisikan gambaran seluruh perangkat lunak/aplikasi yang dihubungkan dengan perkembangan teknologi pendidikan, mengidentifikasikan semua informasi dan kebutuhan dengan melakukan analisis sistem yang berajalan, analisis masalah, analisis data dan analisis proses sistem/aplikasi yang akan dibuat.

Pengumpulan kebutuhan dimulai dari analisis sistem yang telah ada dan sedang digunakan bersama dengan analisis permasalahan metode pembelajaran yang berlangsung pada SMA Negeri 1 Cerenti. Analisis sistem yang sedang berjalan merupakan proses menemukan dan menguraikan permasalahan dengan mengaitkan permasalahan dengan komponen-komponen yang saling berinteraksi pada sistem yang lama. Analisis sistem yang lama merupakan tahapan awal yang bisa menentukan keberhasilan suatu sistem atau aplikasi bisa dibangun atau dikembangkan. Hasil dari analisis ini bisa dijadikan sebagai tema inti dari aplikasi yang akan dikembangkan dan oleh karena itu pada penelitian ini peneliti telah menetapkan sebelumnya untuk membuat sebuah aplikasi pembelajaran tentang pengenalan kebudayaan Melayu di Provinsi Riau yang berbasis android yang nantinya bisa dimanfaatkan oleh guru dan peserta didik/siswa sebagai media pembelajaran pendamping di rumah.

Analisis berikutnya peneliti berusaha menganalisis masalah yang telah ditemukan, dan berusaha menemukan solusi yang tepat. Analisis ini juga untuk mengsinkronkan masalah dengan solusi yang telah didapat, yaitu dengan membuat sebuah aplikasi pembelajaran tentang pengenalan kebudayaan Melayu di 
Provinsi Riau yang berbasis android yang juga sudah ditetukan sebelumnya. Berdasarkan tema tersebut perlu dilakukan analisis proses berjalannya sistem. Analisis proses ini dalam memperkenalkan kebudayaan Provinsi Riau siswa masih melakukan pembelajaran melalui buku kebudayaan Provinsi Riau. Dan guru pun masih menjelaskan melalui papan tulis yang dianggap kurang efektif dan efesien. Dengan adanya aplikasi pengenalan kebudayaan Provinsi Riau diharapkan dapat membantu siswa maupun guru dalam melakukan pembelajaran mengenai kebudayaan Provinsi Riau. Pada saat menggunakan aplikasi ini siswa maupun guru masuk ke dalam aplikasi dan akan tampil menu home yang didalamnya terdapat materi, dari kebudayaan Provinsi Riau, galeri atau gambar dari kebudayaan Provinsi Riau, tentang berisi mengenai sekolah SMA N 1 Cerenti, dan keluar.

Langkah analisis berikutnya analisa data, analisa data merupakan suatu tahap yang penting bagi pengembangan sebuah sistem atau aplikasi, tahapan ini teradapat dua jenis data yang akan dilakukan proses nantinya yakni data masukan (input data), contoh: gambar, teks, video dan lain-lain yang data masukan lainnya yang terkait dalam pembuatan aplikasi pembelajaran tentang kebudayaan yang ada di Provinsi Riau. Analisis data yang kedua adalah data keluaran (output data) yang menghasilkan informasi tentang: 1 . Aplikasi memberikan informasi tentang materi yang ada dalam buku; 2. Apliaksi memberikan informasi mengenai kebudayaan berupa gambar dan teks.

Analisis pengguna juga perlu dilakukan untuk melengkapi segala kebutuhan sistem, nantinya pengguna berperan penting dalam pembuatan dan pengembangan aplikasi pengenalan keberagaman kebudayaan ini, pengguna menjurus kepada siswa kelas $\mathrm{X}$ dan guru. Pengguna dapat dengan mudah mengakses informasi tentang pelajaran kebudayaan yang akan mereka akses menggunakan smartphone yang telah ter-install aplikasi pengenalan kebudayaan yang ada di Provinsi Riau, dapat diakses di mana pun peserta didik/siswa berada dan waktunya bisa kapan saja.

b. Membangun prototyping

Membangun prototyping yaitu peneliti membuat perancangan sistem/aplikasi (perangkat lunak) sementara yang terpusat pada penyajian kebutuhan yang diinginkan pengguna. Tahapan Perancangan prototyping dimulai dari perancagan pemodelan aplikasi yang dibuat pada tahap ini adalah perancangan antarmuka aplikasi smartphone sebagai media pembelajaran tentang pengenalan kebudayaan Melayu di Provinsi Riau yang berbasis android yang terdiri dari: antarmuka awal, antarmuka menu utama (Materi, Galeri, Kuis, About), antarmuka menu materi (Pakaian Melayu Riau, Makanan Khas Riau, Permainan Tradisional, Kuis), antarmuka menu galeri (berisikan photophoto yang berkaitan dengan Budaya Melayu Riau), antarmuka menu about (berisikan tentang STMIK Hang Tuah Pekanbaru dan SMA Negeri 1 Cirenti), dan antarmuka menu keluar.

c. Evaluasi protoptyping

Evaluasi prototyping merupakan tahapan yang dilakukan langsung oleh pengguna dengan di dampingi peneliti dan berusaha menganalisa apakah prototyping aplikasi smartphone sebagai media pembelajaran tentang pengenalan kebudayaan Melayu di Provinsi Riau yang berbasis android yang telah dibuat telah sesuai dengan keinginan dan kebutuhan pengguna. Jika prototyping sudah sesuai maka langsung ke tahapan berikutnya yaitu tahapan keempat untuk dilakukan pengkoding aplikasi dengan bahasa pemrograman. Jika belum, maka perancangan prototyping dirubah sesuai saran dan kritik dari pengguna dengan kembali tahapan sebelumnya yaitu tahapan ke-1, 2, dan ke-3.

d. Mengkodekan sistem

Mengkodekan sistem merupakan bagian dari tahapan kegiatan pembuatan/pengembangan sistem/aplikasi (perangkat lunak) dengan dukungan atau bantuan perangkat lunak lainnya serta menggunakan bahasa pemrograman sesuai dengan perancangan prototyping yang sudah disepakati antara pengguna dan peneliti, bahasa pemrograman yang digunakan bahasa pemrograman Java. Java adalah bahasa berorientasi objek yang dapat dimanfaatkan untuk pembuatan dan pengembangan sistem atau aplikasi secara mandiri oleh pengguna dengan penerapan aplikasi berbasis teknologi internet, serta untuk pengembangan sistem/ aplikasi perangkat pintar yang bisa saling berkomunikasi baik dengan jaringan lokal maupun melalui koneksi internet (Lengkong, Sinsuw, \& Lumenta, 2015). Aplikasi yang membantu dalam pengembangan dan pembuatan aplikasi tentang pengenalan kebudayaan Melayu di Provinsi Riau berbasis android adalah Eclipse. Eclipse merupakan sebuah IDE (Integrated Development 
Environment) biasa digunakan dalam pembuatan atau pengembangan sebuah aplikasi berbasis android dan dapat berjalan disemua platform yang bebas. Perangkat keras yang digunakan adalah smartphone untuk menjalankan aplikasi dan PC (Personal Computer) jinjing dengan spesifikasi CPU intel core I5, RAM 4 GB, HDD 1 TB, dan Graphics Radeon (TM) R5 sebagai mengolah data, merancang dan pembuatan sistem atau aplikasi tentang pengenalan kebudayaan Melayu di Provinsi Riau yang berbasis android.

e. Menguji sistem

Setelah sistem/aplikasi telah selesai dibangun dan menjadi suatu perangkat lunak, langkah selajutnya adalah menguji sistem atau aplikasi. Pengujian sistem atau aplikasi menggunakan sebuah metode pengujian untuk mengetahui apakah fungsi dan modul aplikasi berjalan sesuai harapan pengembang dan pengguna. Metode pengujian sistem/aplikasi (system testing) yang digunakan adalah metode black box. Metode black box adalah merupakan metode pengujian sistem atau aplikasi yang didasari pada fungsionalitas dalam mengolah data input dan output, serta bertujuan untuk menemukan kekurangan dan kesalahan fungsi dari sistem atau aplikasi (Kusniyati \& Sitanggang, 2016). Hasil dari pengujian aplikasi tentang pengenalan kebudayaan Melayu di Provinsi Riau yang berbasis android, terlihat pada tabel 1 berikut:

Tabel 1. Hasil Pengujian dengan Metode Black Box

\begin{tabular}{|c|l|l|l|l|}
\hline $\begin{array}{c}\text { N } \\
\text { o }\end{array}$ & $\begin{array}{c}\text { Skenario } \\
\text { Pengujian }\end{array}$ & $\begin{array}{l}\text { Hasil yang } \\
\text { Diharapkan }\end{array}$ & $\begin{array}{l}\text { Hasil } \\
\text { Pengujan }\end{array}$ & $\begin{array}{c}\text { Kesim } \\
\text { pulan }\end{array}$ \\
\hline 1. & $\begin{array}{l}\text { Memilih icon } \\
\text { menu Materi }\end{array}$ & $\begin{array}{l}\text { Beralih } \\
\text { kalaman } \\
\text { Materi }\end{array}$ & $\begin{array}{l}\text { Sesuai } \\
\text { dengan } \\
\text { yang } \\
\text { diharapkan }\end{array}$ & Valid \\
\hline 2. & $\begin{array}{l}\text { Memilih icon } \\
\text { menu galeri }\end{array}$ & $\begin{array}{l}\text { Beralih ke } \\
\text { menu galeri }\end{array}$ & $\begin{array}{l}\text { Sesuai } \\
\text { dengan } \\
\text { yang } \\
\text { diharapkan }\end{array}$ & Valid \\
\hline 3. & $\begin{array}{l}\text { Memilih } \\
\text { icon menu } \\
\text { about icon }\end{array}$ & $\begin{array}{l}\text { Beralih ke } \\
\text { menu } \\
\text { about }\end{array}$ & $\begin{array}{l}\text { Sesuai } \\
\text { dengan } \\
\text { yang } \\
\text { diharapkan }\end{array}$ & Valid \\
\hline 4. & $\begin{array}{l}\text { Memilih icon } \\
\text { menu keluar }\end{array}$ & $\begin{array}{l}\text { Mengeluark } \\
\text { an opsi } \\
\text { pilihan } \\
\text { keluar }\end{array}$ & $\begin{array}{l}\text { Sesuai } \\
\text { dengan } \\
\text { yang } \\
\text { diharapkan }\end{array}$ & Valid \\
\hline 5. & $\begin{array}{l}\text { Memilih } \\
\text { menu } \\
\text { quis }\end{array}$ & $\begin{array}{l}\text { Mengeluark } \\
\text { an opsi } \\
\text { apakah } \\
\text { jawaban } \\
\text { benar atau } \\
\text { salah }\end{array}$ & $\begin{array}{l}\text { Sesuai } \\
\text { dengan } \\
\text { yang } \\
\text { diharapkan }\end{array}$ & Valid \\
\hline
\end{tabular}

f. Evaluasi sistem

Tahap berikutnya adalah evaluasi terhadap sistem atau aplikasi tentang pengenalan kebudayaan Melayu di Provinsi Riau berbasis android. Evaluasi dilakukan pengguna yaitu SMA Negeri 1 Cirenti, pengguna akan mengevaluasi setelah sistem atau aplikasi dilakukan pengujian sebelumnya. Evaluasi ini mencakup kebutuhan pengguna untuk mengetahui apakah sudah terpenuhi atau ada bagian fungsional sistem yang belum berjalan sesuai perancangan prototype-nya, dan jika belum maka peneliti akan memperbaiki dan mengulangi tahapan sebelumnya, tahapan 4 dan 5.

g. Menggunakan sistem

Aplikasi tentang pengenalan kebudayaan Melayu di Provinsi Riau berbasis android telah selesai dibangun dan dikembangan, selanjutnya aplikasi diserahkan kepada pengguna yakni SMA Negeri 1 Cirenti. Berikut tampilan dari aplikasi tersebut:

1. Halaman Splash Screen

Halaman splashscreen pada tampilan awal dari aplikasi tentang pengenalan kebudayaan Melayu di Provinsi Riau berbasis android, halaman ini hanya akan terbuka beberapa detik dan secara otomatis berpindah halaman menu utama, seperti yang terlihat pada gambar di bawah ini:

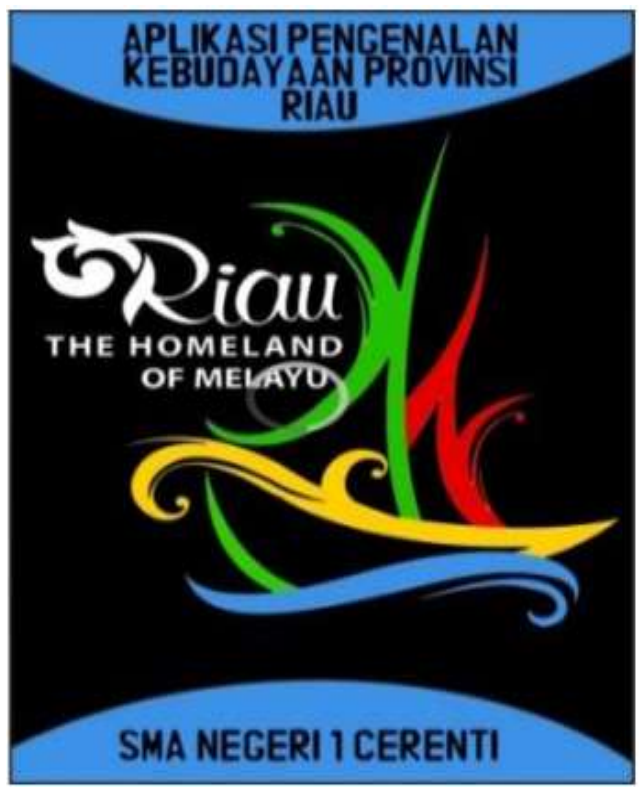

Gambar 4. Halaman Splash Screen

2. Tampilan Menu Utama

Pada halaman menu utama diawali dengan empat menu utama yaitu menu "Materi", "Galeri”, “About", "Keluar". Setiap Tombol 
akan menuju ke masing-masing kategori. Berikut tampilan halaman menu utama pada gambar 5:

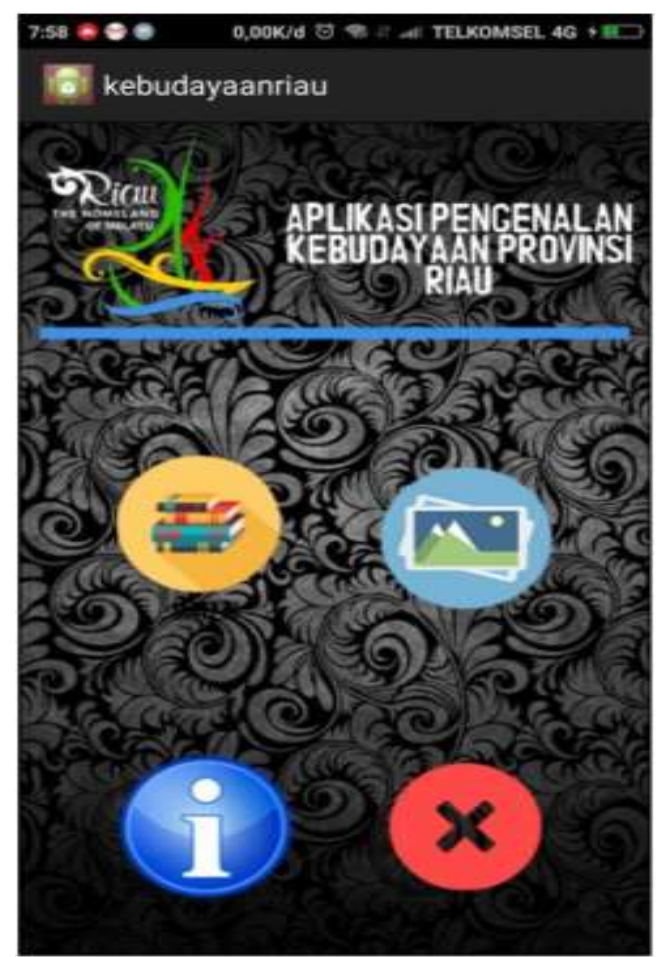

Gambar 5. Tampilan Menu Utama

3. Tampilan Menu Materi

Berikut tampilan setelah pengguna memilih menu materi pengenalan kebudayaan, maka pengguna akan melihat tampilan kategori materi, seperti pada gambar 6 berikut:

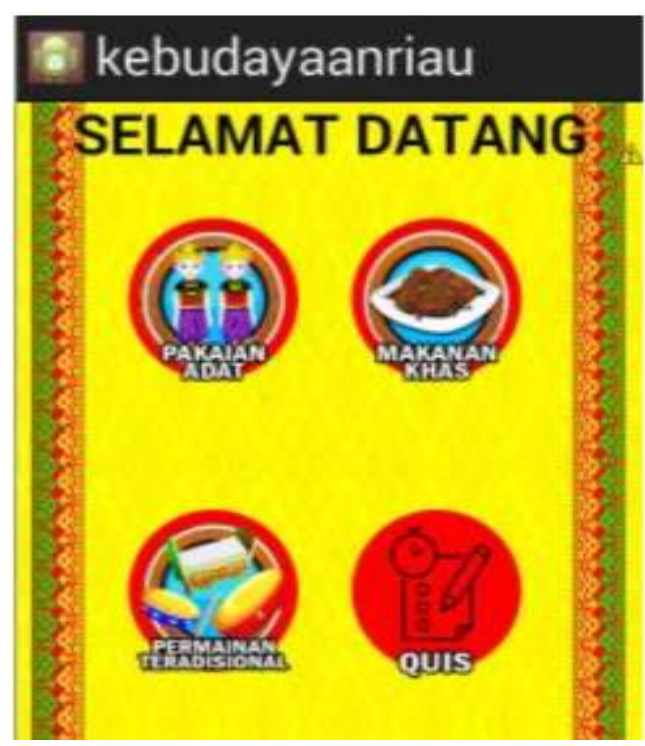

Gambar 6. Tampilan Menu Materi
Berikutnya tampilan menu pakaian adat yang dipilih pengguna, maka pengguna akan diarahkan ke tampilan yang terlihat pada gambar 7 berikut:

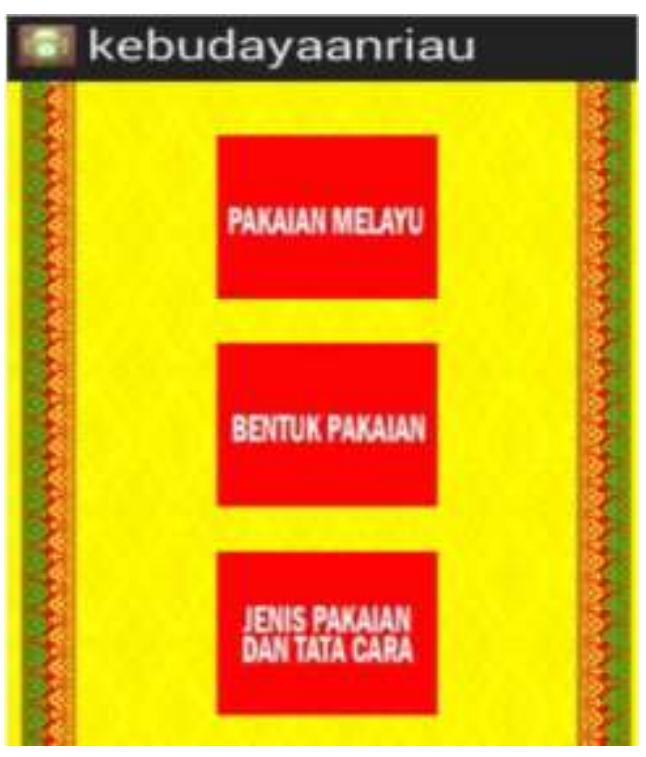

Gambar 7. Tampilan Menu Pakaian Adat

Tampilan berikut adalah ketika pengguna memilih salah satu menu dari pakaian melayu, maka pengguna akan diarahkan ke salah satu tampilan pakaian seperti di bawah ini:
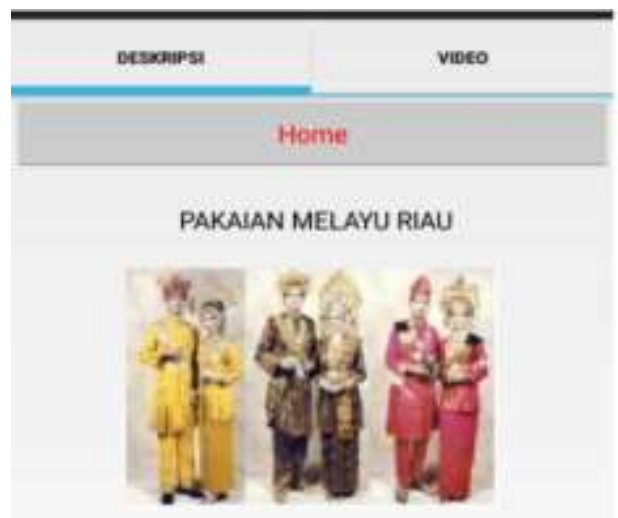

spakaian meiand

Sebuah karya seni bica dibilang indah apabila dibsat dengan bak dan mempunyai makna. Sebogai huatu hasil kebudeyaan. Pakaian Melayn Kepulauan kasu idealrys hendaklah indah bila dihtat dan

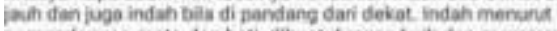
pemsndangan mato dan hati, dibuat denyan bak dan mempenya makna maina yang tenkandong idalsm lambing larrkanc Bagi orang Melayi pakaian selain berfungsi sebagai penutup auzat dan pelindung tbuh dan panas dan dingin jugu aebags: lambiro.

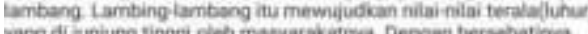
yang di junjung tingei cieh matyarakitiva. Dengwi bersebaticys

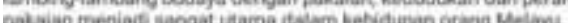

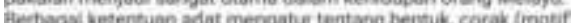

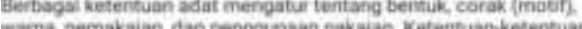

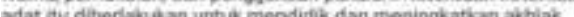
kngafa orang Yang memakairmi

Gambar 8. Tampilan Salah Satu Menu Pakaian Melayu Riau 
Gambar berikut adalah ketika memilih menu ragam makanan, maka pengguna akan diarahkan ke tampilan seperti di bawah ini:

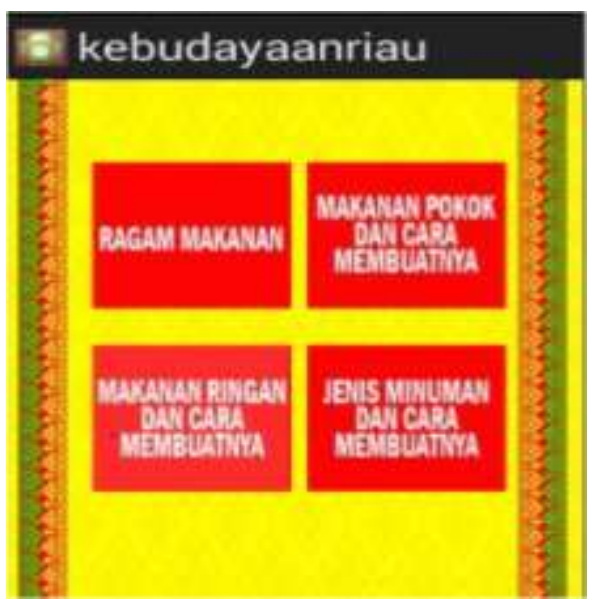

Gambar 9. Tampilan Menu Makanan Khas

Berikut tampilan setelah pengguna memilih salah satu menu makanan, maka pengguna akan melihat salah satu contoh tampilan makanan yang terlihat di bawah ini:

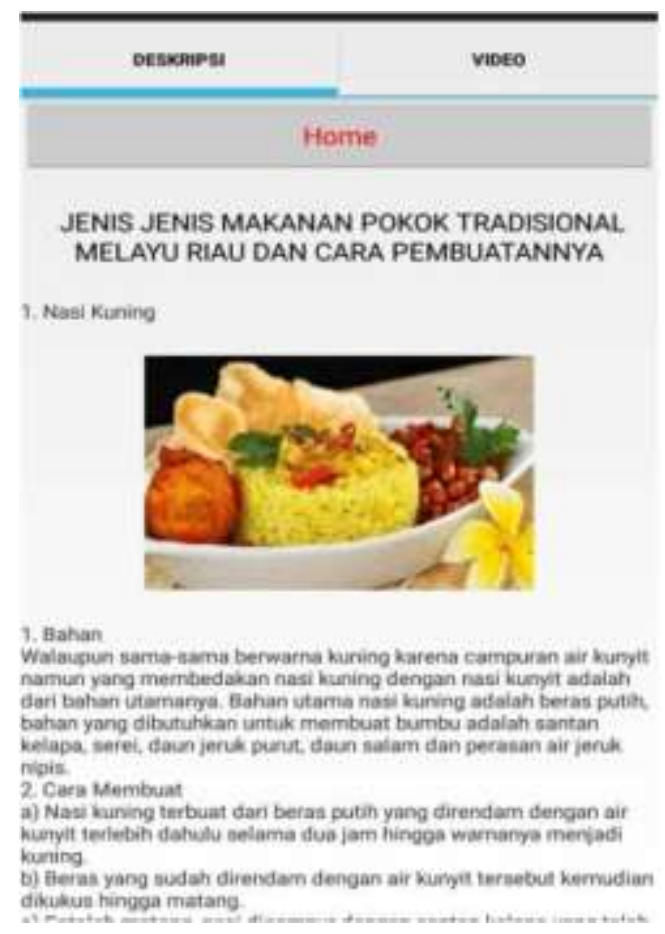

Gambar 10. Tampilan Salah Satu Menu Pakaian

Tampilan berikut ini adalah menu permainan tradisional, maka pengguna akan diarahkan ke tampilan seperti Gambar seperti di bawah ini:

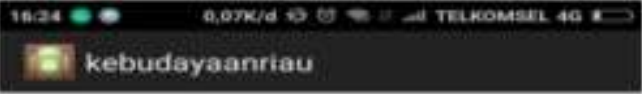

sueas

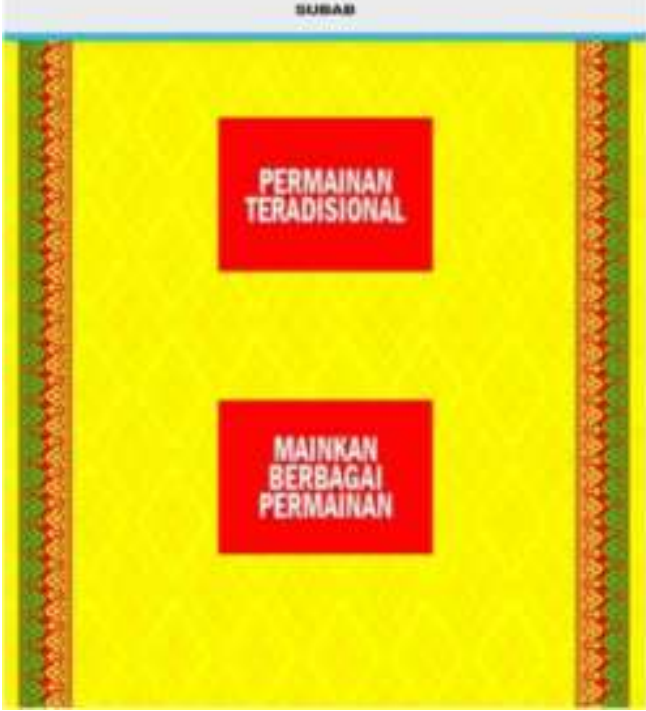

Gambar 11. Tampilan Menu Permainan Tradisional

Selanjutnya tampilan setelah pengguna memilih salah satu menu permainan tradisional, dan pengguna akan melihat salah satu contoh tampilan permainan tradisional Seperti di bawah ini:

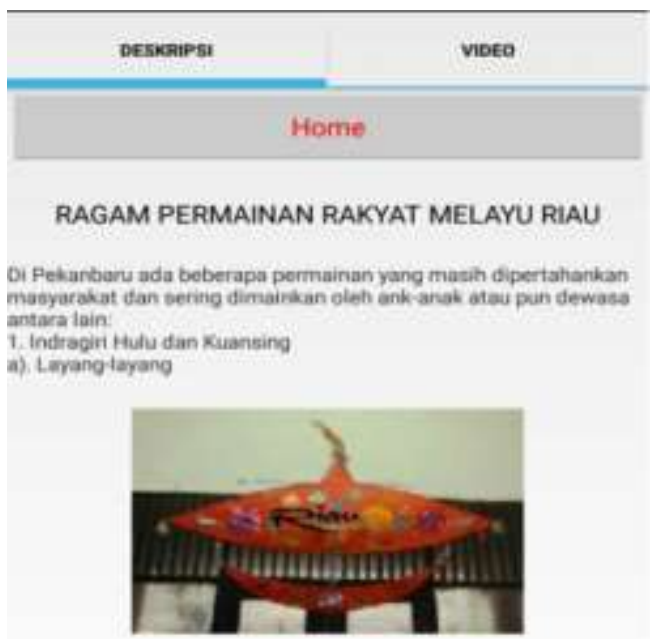

Lipang layang termasuk sainh satu permainan rakyst daerah fan. Pade imumny lakno-layang terhat dari kertas oteu kain perasut ano diberi kerangea dan dapat ditertangkan ke anokass denoag bantuan angina seteluh d kaitican podta seutas tall atau benang

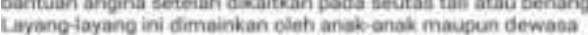
Lityonglayang ini dimainkan oleh ansik anak maupun dewaba ditanah lapangan poda musim kemarau ataus selepan panen. layang-layang diadu, maka bagan ujung diberi (ditempeckan) awan dapat memutuskan tall layang iayang lawan itu Layang layang yanag paing barygk memutuskan tol layang-iayang lawa dipandang ebagai pemenang atau yang terkuat, ada juga yang

Gambar 12. Tampilan Salah Satu Menu Permainan Tradisional

Kembali ke menu utama untuk mengikuti quis, pengguna harus memilih menu quis, 
berikut tampilan menu quis, seperti terlihat di bawah ini:

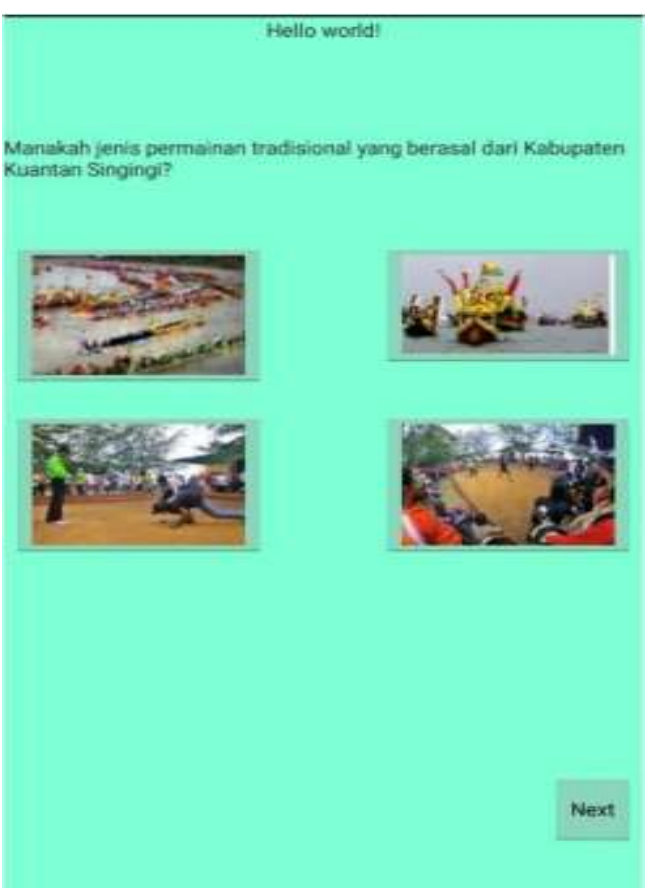

Gambar 13. Tampilan Menu Quis

4. Tampilan Menu Galeri

Berikut tampilan setelah pengguna memilih menu galeri, maka pengguna akan melihat isi menu galeri, seperti gambar di bawah ini:

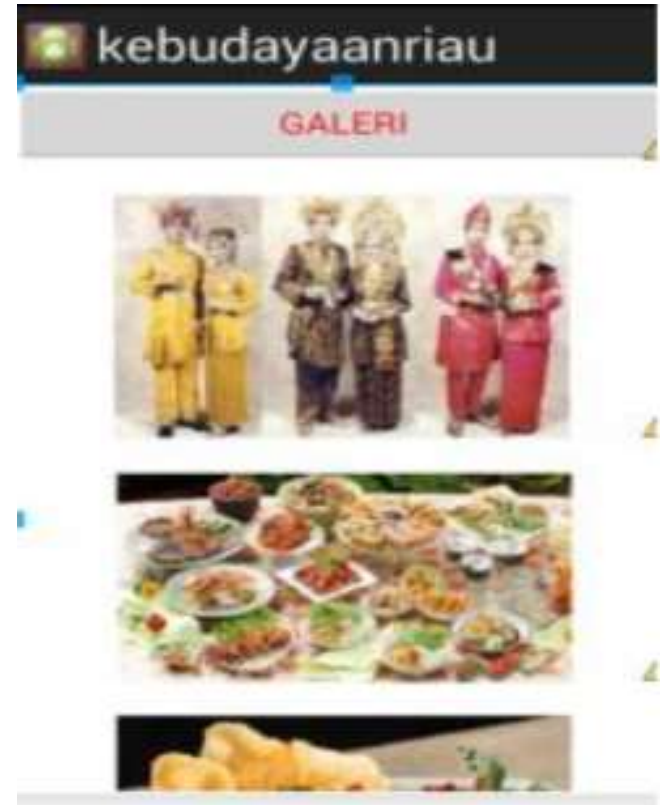

Gambar 14. Tampilan Galeri

5. Tampilan Menu About

Tampilan setelah pengguna memilih menu "About", maka pengguna akan diarahkan ke kategori "About", seperti tampilan gambar 15 berikut:

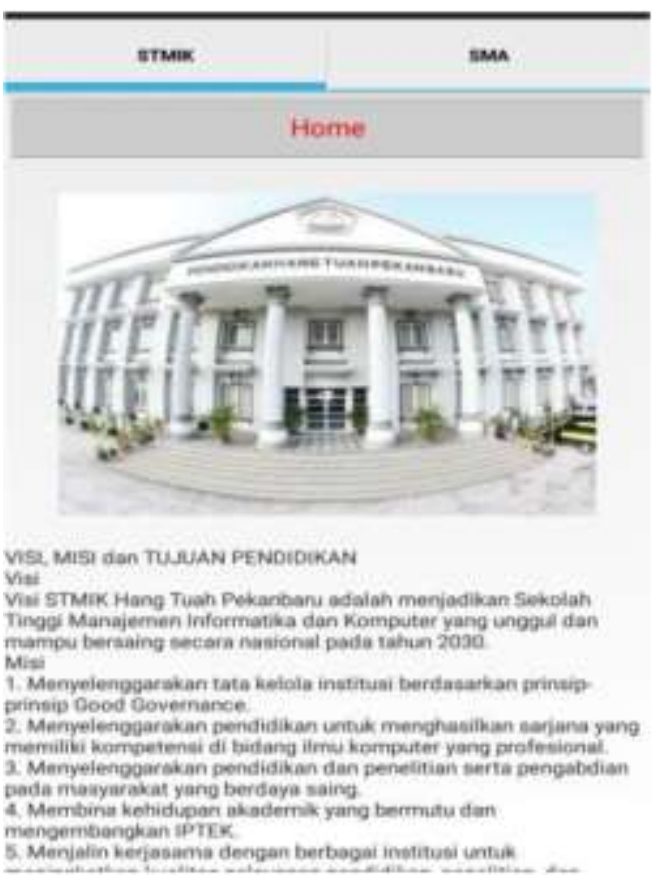

Gambar 15. Tampilan Menu About

6. Tampilan Menu Keluar

Untuk keluar pengguna harus memilih menu keluar, maka pengguna akan melihat tampilan menu keluar dengan sebuah pertanyaan seperti di bawah ini:

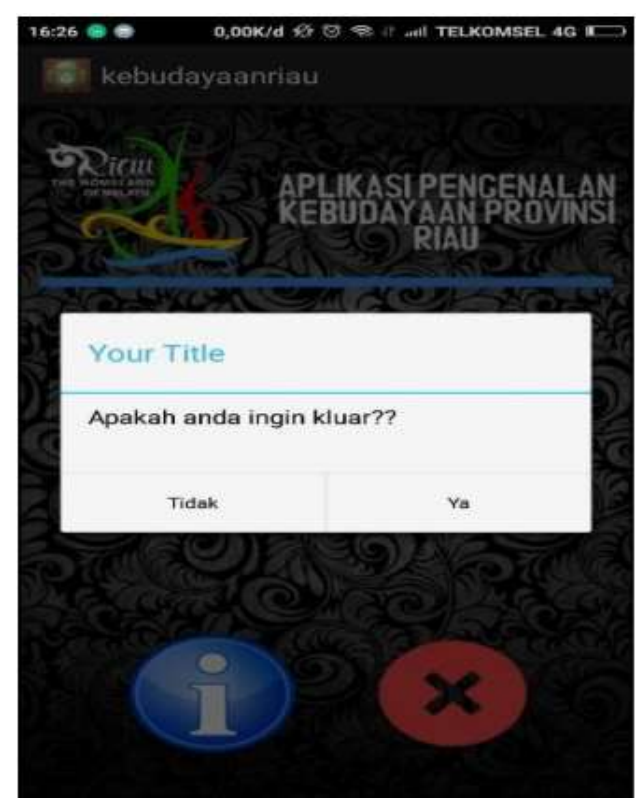

Gambar 16. Tampilan Menu Keluar 


\section{Kesimpulan}

Dari hasil pembahasan pada penelitian ini, maka peneliti dapat menyimpulkan setelah pembuatan dan pengembangan serta pengujian Aplikasi Pengenalan Kebudayaan Provinsi Riau di SMA Negeri 1 Cerenti Berbasis Android ini bahwa Aplikasi pengenalan kebudayaan Provinsi Riau ini dapat membantu guru, dapat meningkatkan ketertarikan dan minat belajar para peserta didik/siswa di SMA Negeri 1 Cerenti dalam mempelajari kebudayaan yang ada di Provinsi Riau. Aplikasi pengenalan kebudayaan dapat digunakan sebagai media pembelajaran yang mudah untuk dipahami siswa/siswi di SMA Negeri 1 Cerenti dengan menggunakan android yang bisa diakses oleh guru dan pesert didik/siswa di rumah.

\section{References}

Daeng, I. T. M., Mewengkang, N. N., \& Kalesaran, E. R. (2017). Penggunaan Smartphone Dalam Menunjang Aktivitas Perkuliahan Oleh Mahasiswa Fispol Unsrat Manado. Acta Diurna, Vol. VI(No. 1), 1-15.

Hasibuan, N. (2015). Implementasi Teknologi Pendidikan dalam Pendidikan Islam. Logaritma, Vol. III(No. 02), 100-115.

Kosidin, \& Farizah, R. N. (2016). Pemodelan aplikasi mobile reminder berbasis android. Seminar Nasional Teknologi Informasi Dan Komunikasi 2016, 2016(Sentika), 271-280.

Kusniyati, H., \& Sitanggang, N. S. P. (2016). Aplikasi Edukasi Budaya Toba Samosir Berbasis Android. Jurnal Teknik Informatika, Vol. 9(No. 1), 9-18. https://doi.org/https://doi.org/10.15408/jti.v9 i1.5573

Kuswanto, J., \& Radiansah, F. (2018). Media Pembelajaran Berbasis Android Pada Mata Pelajaran Sistem Operasi Jaringan Kelas XI. Jurnal Media Infotama, Vol. 14(No. 1), 1520.

Lengkong, H. N., Sinsuw, A. A. E., \& Lumenta, A. S. M. (2015). Perancangan Penunjuk Rute Pada Kendaraan Pribadi Menggunakan Aplikasi Mobile GIS Berbasis Android Yang Terintegrasi Pada Google Maps. E-Journal Teknik Elektro Dan Komputer, Vol. 4(No. 2), $18-25$.

https://doi.org/https://doi.org/10.35793/jtek.4 .2.2015.6817

Maisyaroh, Mulyani, A., \& Juanda, A. (2017). Rancang Bangun Aplikasi Pembelajaran Tabel Periodik Unsur Kimia Berbasis Android. Jurnal Bianglala Informatika, Vol. 5(No. 2), 108-114.
Muyaroah, S., \& Fajartia, M. (2017). Pengembangan Media Pembelajaran Berbasis Android dengan menggunakan Aplikasi Adobe Flash CS 6 pada Mata Pelajaran Biologi Abstrak. Innovative Journal of Curriculum and Educational Technology, Vol. 6(No. 2), 79-83. Retrieved from https://journal.unnes.ac.id/sju/index.php/ujet

Nurfuadi, I. (2015). Rancang Bangun Media Pembelajaran Pengenalan Budaya Indonesia Berbasis Android Menggunakan Phonegap. Universitas Islam Negeri Alauddin Makassar.

Panji, A. (2014). Hasil Survei Pemakaian Internet Remaja Indonesia. Retrieved September 21, 2019 , from https://tekno.kompas.com/read/2014/02/19/1 623250/hasil.survei.pemakaian.internet.re\%2 520maja.indonesia

Pressman, R. S. (2012). Rekayasa Perangkat Lunak (Pendekatan Praktisi) (Ed.7). Yogyakarta: Andi.

Rifa'atunnisa, Satria, E., \& Cahyana, R. (2014). Pengembangan Aplikasi Zakat Berbasis Android Menggunakan Metode Prototype. Jurnal Algoritma, Vol. 11(No. 1), 1-7. Retrieved from http://jurnal.sttgarut.ac.id

Sujono, Mayasari, M. S., \& Koloniawan. (2019). Prototipe Aplikasi Simpan Pinjam Pada Koperasi Darma Karya Pangkalpinang Babel. Jurnal SISFOKOM, Vol. 08(No. 01), 68-73.

Tumanggor, R., Kholis, R., \& Nurochim. (2017). Ilmu Sosial dan Budaya Dasar. (E. Wahyudin, Ed.) (Ke Tiga). Jakarta: Kencana.

UU RI No. 20 Th. 2003. Sistem Pendidikan Nasional, Pub. L. No. Lembaran Negara Republik Indonesia Nomor 4301 (2003). Indonesia.

Widiyanto, W. W. (2018). Analisa Metodologi Pengembangan Sistem Dengan Perbandingan Model Perangkat Lunak Sistem Informasi Kepegawaian Menggunakan Waterfall Development Model, Model Prototype, dan Model Rapid Application Development (RAD). Jurnal INFORMA Politeknik Indonusa Surakarta, Vol. 4(No. 1), 34-40.

Yusuf, E. M., \& Kaniawulan, I. (2015). Pengembangan Prototipe Sistem Informasi Geografis Fasilitas Olahraga Berbasis Mobile (Studi Kasus Fasilitas Olahraga Di Kecamatan Purwakarta) Program Studi Teknik Informatika Sekolah Tinggi Teknologi Wastukancana Jalan Raya Cikopak Sadang No 54 Purwakarta. Riau Journal Of Computer Science, Vol. 1(No. 1), $57-68$. 
Zahid, M. Z. (2018). Aplikasi Berbasis Android untuk Pembelajaran: Potensi dan Metode Pengembangan. In Prosiding Seminar Nasional Matematika (Vol. 1, pp. 910-918).
Semarang: Universitas Negeri Semarang. Retrieved from https://journal.unnes.ac.id/sju/index.php/pris mal 